\title{
Pendampingan Penyusunan Laporan Keuangan Pada KPRI Karya Praja Bakorwil I Madiun
}

\author{
Siti Suharni ${ }^{1}$, Fatchur Rochman ${ }^{2}$ \\ ${ }^{1}$ Program Studi Akuntansi, Universitas Merdeka Madiun, Jl.Serayu No.79, Madiun, 63133 \\ E-mail: sitisuharni@unmer-madiun.ac.id \\ ${ }^{2}$ Program Studi Akuntansi, Universitas Merdeka Madiun, Jl.Serayu No.79, Madiun, 63133 \\ E-mail: fatchurrochman@unmer-madiun.ac.id
}

\begin{abstract}
Entity Financial Accounting Standards Without Public Accountability (SAK ETAP) that are used for entities without public accountability. SAK ETAP is an entity that does not have significant public accountability and publishes general purpose financial statements for external users such as owners who are not directly involved in business management, creditors, and credit rating agencies. For this reason, KPRI Karya Praja needs to understand and compile financial reports according to these regulations. The purpose of this community service is to assist the KPRI Karya Praja management in preparing financial reports in accordance with SAK ETAP and the Cooperative Law, namely by providing assistance. The benefit of this assistance is that the KPRI Karya Praja management is expected to understand the presentation and preparation of the correct financial statements in accordance with SAK ETAP and the Cooperative Act. The method used by the socialization of SAK ETAP and the Cooperative Act was continued with assistance in preparing financial statements. The results of this activity provide knowledge and understanding to the administrative, bookkeeping and treasurer sections on the basics of bookkeeping, code adjustments and account classification based on Financial Accounting Standards ETAP and Cooperative Law and provide assistance in the preparation of correct financial statements in accordance with ETAP Financial Statements and Laws. About Cooperatives.
\end{abstract}

Keywords-: Assistance; Preparation of Financial Statements.

\section{PENDAHULUAN}

Seiring dengan pesatnya perkembangan usaha-usaha di Indonesia, pada tanggal 23 Oktober 2010 telah terbit dan disahkan oleh Dewan Standar Akuntansi Keuangan tentang Exposure Draft Pernyataan Pencabutan Standar Akuntansi Keuangan yaitu pencabutan Pernyataan Standar Akuntansi Keuangan (PSAK) No. 27 tentang akuntansi perkoperasian. Pencabutan PSAK No. 27 dilandasi alasan sebagai dampak dari konvergensi IFRS yang mengakibatkan SAK berbasis industri harus dicabut karena sudah diatur dalam SAK lain. Sebagai pengganti PSAK No. 27, kini telah terbit Standar Akuntansi Keuangan Entitas Tanpa Akuntabilitas Publik (SAK ETAP) yang digunakan untuk entitas tanpa akuntabilitas publik. Entitas tanpa akuntabilitas publik adalah entitas yang tidak memiliki akuntabilitas publik signifikan dan menerbitkan laporan keuangan untuk tujuan umum (general purpose financial statement) bagi pengguna eksternal seperti pemilik yang tidak terlibat langsung dalam pengelolaan usaha, kreditur, dan lembaga pemeringkat kredit.

SAK ETAP diterapkan untuk penyusunan laporan keuangan yang dimulai pada atau setelah 1 Januari 2011. Penerapan dini diperkenankan. Jika SAK ETAP diterapkan dini, maka entitas harus menerapkan SAK ETAP untuk penyusunan laporan keuangan yang dimulai pada atau setelah 1 Januari 2010. Tujuan laporan keuangan adalah menyediakan informasi posisi keuangan, kinerja keuangan, dan laporan arus kas suatu entitas yang bermanfaat bagi sejumlah besar pengguna dalam pengambilan keputusan ekonomi oleh siapapun yang tidak dalam posisi dapat meminta laporan keuangan khusus untuk memenuhi kebutuhan informasi tertentu. Dalam memenuhi tujuannya, laporan keuangan juga menunjukkan apa yang telah dilakukan manajemen (stewardship) atau pertanggungjawaban manajemen atas sumber daya yang dipercayakan kepadanya (SAK ETAP paragraf 2.1).

Dalam laporan keuangan tercatat semua transaksi yang terjadi pada koperasi selama satu periode, sehingga pemakai dapat mengetahui manfaat yang diperoleh sebagai anggota koperasi selama satu periode dengan Sisa Hasil Usaha (SHU) yang diperoleh sumber daya ekonomi yang dimiliki dan dapat diketahui pula kewajiban dan kekayaan bersihnya. Keterbatasan pengetahuan manajemen mengakibatkan kesulitan untuk menganalisis lingkungan usaha, ketidakmampuan dalam mengidentifikasikan peluang-peluang yang ada dalam lingkungan, sehingga pada akhirnya akan menemui kesulitan dalam menyusun perencanaan, khususnya perencanaan dalam keuangan. Kurangnya tenaga terampil akan mengakibatkan tidak teraturnya sistem pembukuan dan kurangnya pemahaman tentang penyusunan laporan keuangan koperasi sesuai dengan SAK ETAP dan Undang-Undang Perkoperasian.

Dengan melihat permasalahan di atas dan untuk mengetahui apakah KPRI Karya Praja termasuk dalam entitas tanpa akuntabilitas publik dan apakah KPRI Karya Praja menerapkan SAK ETAP, maka tim pengabdian masyarakat tertarik melakukan pendampingan terhadap penyusunan laporan keuangan yang sesuai dengan SAK ETAP dan Undang-Undang Perkoperasiandi 
Website : http://dayamas.unmermadiun.ac.id/index.php/dayamas

\section{METODE PENELITIAN}

Kegiatan pengabdian masyarakat ini berupa pendampingan pada KPRI Karya Praja. Untuk mengimplementasikan tersebut, kegiatan pertama yang dilakukan adalah dengan melakukan sosialisasi kepada semua pengurus dan kedua melakukan pendampingan terhadap pengurus yang terlibat langsung pada penyusunan laporan keuangan dengan menggunakan metode pendekatan langsung ke lapangan dengan cara melihat langsung semua transaksi yang sudah dibukukan oleh bagian pembukuan atau dokumentasi, adapun untuk menyelesaikan permasalahan tersebut, yaitu dengan beberapa metode sebagai berikut :

\section{A. Metode Observasi}

Merupakan teknik pengumpulan data, dimana peneliti melakukan pengamatan secara langsung ke objek penelitian untuk melihat dari dekat kegiatan yang dilakukan. Metode observasi sering kali diartikan sebagai pengamatan dan pencatatan secara sistematik terhadap gejala yang tampak pada subyek penelitian. Teknik observasi sebagai pengamatan dan pencatatan secara sistematik hendaknya dilakukan pada subyek yang secara aktif mereaksi terhadap obyek. Adapun kriteria yang hendak diperhatikan oleh observeser antara lain.

\section{B. Metode Wawancara}

Wawancara adalah proses memperoleh keterangan untuk tujuan penelitian dengan cara tanya jawab langsung antara tim pendamping dengan bagian yang terlibat langsung dengan pencatatan pembukuan. Keterangan-keterangan yang hendak diperoleh melalui wawancara biasanya adalah keterangan dalam memperoleh dan memastikan fakta, memperkuat kepercayaan, memperkuat perasaan, mengenali standar kegiatan, dan untuk mengetahui alasan seseorang.

\section{Metode Dokumentasi}

Mengumpulkan data atau informasi tentang hal-hal yang ada kaitannya dengan pengabdian, dengan jalan melihat kembali sumber tertulis yang lalu baik berupa angka atau keterangan. Dalam kegiatan ini, metode dokumentasi dilakukan dengan mengumpulkan data dari dokumen yang ada pada KPRI Karya Praja berupa laporan keuangan bulanan.

\section{Metode Sosialisasi}

Metode sosialisasi adalah cara yang sistematis untuk mencapai suatu tujuan yang lelah direncanai melalui diskusi, rapat dan pertemuan praktek. Setiap orang belajar melelui banyak cara yang berbeda - beda sesui dengan kemampuan menangkap pesan yang diterima, ada yang cukup mendengar saja, atau melihat dan juga ada yang harus mempraktekkan dan kemudian mendistribusikannya.

\section{E. Metode Pendampingan}

Pendampingan merupakan suatu kegiatan yang bermaksud untuk memperbaiki dan mengembangkan sikap, tingkah laku keterampilan, dan pengetahuan dari karyawannya sesuai dengan keinginan perusahaan. Pendampingan juga merupakan proses sistematis dimana karyawan mempelajari pengetahuan (knowledge), keterampilan (skill), kemampuan (ability) atau perilaku terhadap tujuan pribadi dan organisasi.

\section{III.HASIL DAN PEMBAHASAN}

Dari hasil observasi wawancara yang telah dilakukan oleh tim pengabdian maka dapat diperoleh keterangan bahwa IKM Kripik Tempe Kilodang Tawangrejo Takeran belum pernah melakukan aktivitas pembukuan.Banyak kendala yang dihadapi, diantaranya mereka menganggap pembukuan terlalu ribet untuk dilakukan. Hal ini disebabkan latar belakang pendidikan ( SDM yang kurang memadai ) dan kurangnya sosialisasi dari daerah mereka.

Berdasarkan kenyataan di lapangan dan untuk mengatasi hal tersebut, maka diadakannya sosialisasi dan pendampingan tentang penyusunan laporan keuangan sesuai dengan SAK ETAP dan Undang-Undang Perkoperasian bagi KPRI. Diawali dengan memberikan pemahaman tentang SAK ETAP dan UU Perkoperasi yang mengatur tentang kode etik penyusunan laporan keuangan yang benar. Laporan keuangan yang sesuai dengan SAK ETAP dan UU Perkoperasian merupakan hal yang sangat penting bagi semua koperasi. Karena dengan penyusunan laporan keuangan yang benar akan diketahui perkembangan KPRI dan mempermudah untuk mendapatkan modal dari pihak-pihak yang mempunyai keinginan menanamkan modal di KPRI

Pendampingan Penyusunan Laporan Keuangan adalah sebagai berikut :

Format Pengklasifikasian kode rekening dalam laporan keuangan:

Neraca

KPRI Karya Praja

\begin{tabular}{|c|c|c|c|}
\hline $\begin{array}{l}\text { Kode } \\
\text { Rek. }\end{array}$ & Keterangan & $\begin{array}{l}\text { Kode } \\
\text { Rek. }\end{array}$ & Keterangan \\
\hline $\begin{array}{l}1111 \\
1121 \\
1131 \\
1132\end{array}$ & $\begin{array}{l}\text { Asset Lancar: } \\
\text { Kas } \\
\text { Bank } \\
\text { Piutang uang } \\
\text { Piutang barang } \\
\text { konsumsi } \\
\end{array}$ & $\begin{array}{l}2143 \\
2145\end{array}$ & $\begin{array}{l}\text { Dana Sosial } \\
\text { Dana Pendidikan } \\
\text { Dana Resiko } \\
\text { Simpanan } \\
\text { manasuka } \\
\end{array}$ \\
\hline
\end{tabular}


Website : http://dayamas.unmermadiun.ac.id/index.php/dayamas

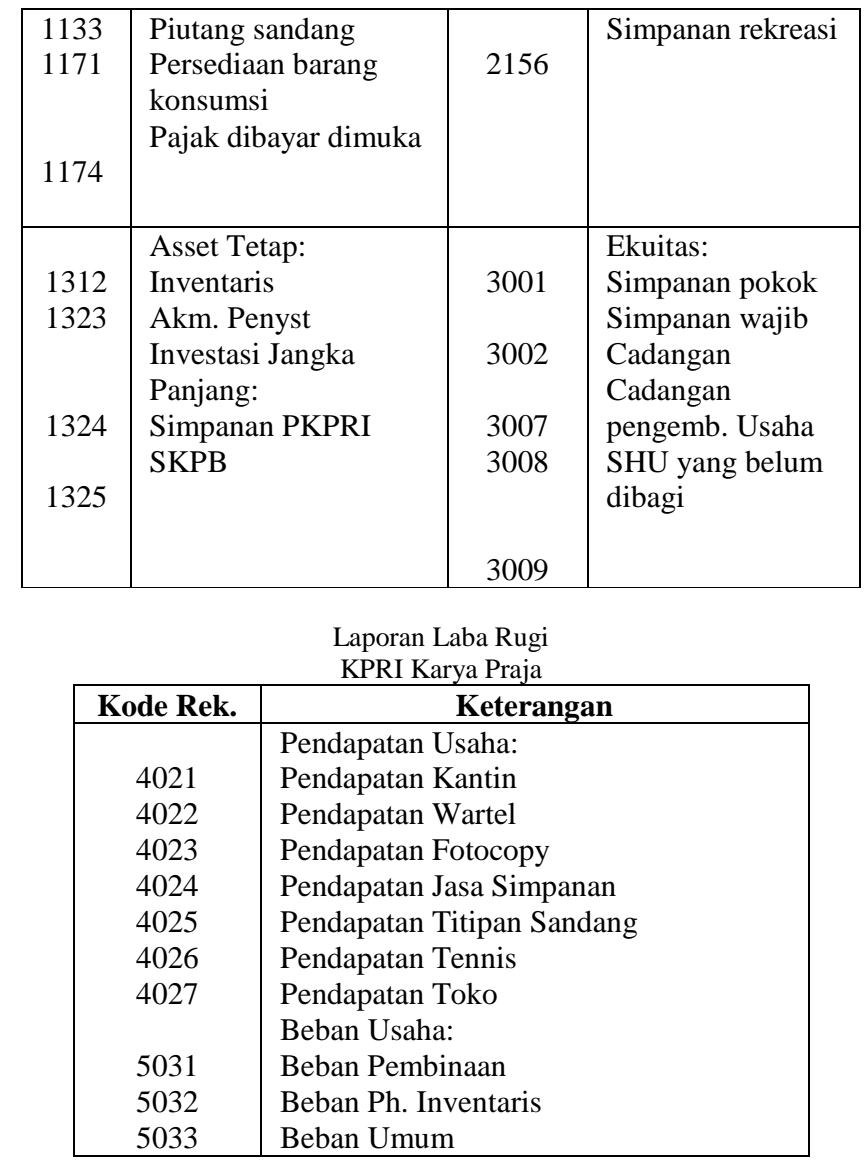

Dengan mengetahui kode rekening setiap transaksi dan golongan setiap transaksi tersebut mereka lebih bisa memahami dan mengerjakan pembukuan dalam penyusun laporan keuangan sesuai dengan SAK ETAP dan UU Perkoperasian setiap tahunnya.

\section{IV.KESIMPULAN}

Solusi yang diharapkan oleh mitra adalah melakukan pendampingan supaya laporan keuangan tersusun sesuai dengan SAK ETAP dan Undang-Undang Perkoperasian. Akuntansi Keuangan ETAP dan Undang-Undang Perkoperasian. Standar Akuntansi Keuangan Entitas Tanpa Akuntabilitas Publik (SAK ETAP) yang digunakan untuk entitas tanpa akuntabilitas publik. Entitas tanpa akuntabilitas publik adalah entitas yang tidak memiliki akuntabilitas publik signifikan dan menerbitkan laporan keuangan untuk tujuan umum (general purpose financial statement) bagi pengguna eksternal seperti pemilik yang tidak terlibat langsung dalam pengelolaan usaha, kreditur, dan lembaga pemeringkat kredit.

Pendampingan di sini dimaksudkan untuk membantu mereka menyusun laporan keuangan yang sesuai dengan SAK ETAP dan Undang-Undang Perkoperasian, dengan tahapan sebagai berikut :

1. Memberikan sosialisasi yang bertujuan agar mereka memahami tentang pengkodean rekening dan pengklasifikasian setiap kegiatan yang dijalankan.

2. Pendampingan penyusunan laporan keuangan sehingga penyusunan laporan keuangan benar sesuai dengan SAK ETAP dan

Undang-Undang Perkoperasian.

\section{DAFTAR PUSTAKA}

IKAPI.1997. Undang-Undang Republik Indonesia No. 25 tahun 1992 Tentang Perkoperasian. Semarang CV. Aneka Ilmu.

Ikatan Akuntan Indonesia. 2009. Standar Akuntansi Keuangan Entitas Tanpa Akuntabilitas Publik (SAK ETAP). Dewan Standar Akuntansi Keuangan.

Ikatan Akuntan Indonesia. 2010. Exposure Draft Pernyataan Pencabutan Standar Akuntansi Keuangan No. 27 Tentang Akuntansi Perkoperasian. Dewan Standar Akuntansi Keuangan.

Sumarsono. 2003. Manajemen Koperasi Teori dan Praktek. Edisi Pertama. Graha Ilmu. Yogyakarta.

Syarief Basir, CPA, SH, MBA. 2010. Newsletter, Akuntansi, Audit, Perpajakan, dan Manajemen. Kantor Akuntan Publik Syarief Basir dan Rekan. 